\title{
Selection of a Brucella vaccine strain of low residual virulence by chemical mutagenesis
}

\author{
W.-R. ZHAO, WENDOSO, HASI, Y.-X. QIN, WANG WENG and S.-L. LU* \\ Institute of Endemic Disease Control, Huhehot, Inner Mongolia, and *Institute of Epidemiology and Microbiology, \\ PO Box 5, Changping, Beijing, China
}

\begin{abstract}
Summary. Following incubation of the oral vaccine Brucella suis strain 2 with diethyl sulphate (DES), a mutant designated strain S105 was selected by screening surviving bacteria for reduced virulence for mice. Strain 105 also showed low residual virulence for guinea-pigs and, unlike the parent strain, did not initiate abortion in pregnant sheep and goats after parenteral administration. Nevertheless, it was as effective as the parent strain in stimulating protective immunity to Brucella melitensis when given as an oral vaccine to sheep under both experimental and field conditions.
\end{abstract}

\section{Introduction}

The use of mutagenic agents to produce living organisms with novel properties is now well established (Pelecanos and Anderson, 1964; Auerbach, 1967). The genetic approach to the production of new organisms has recently received increased attention in relation to the development of new bacterial vaccines. In the field of brucellosis vaccines this approach was adopted about 30 years ago for the selection of strains of reduced virulence. Thus Elberg and Faunce (1957) used streptomycin as the selective agent to derive the attenuated streptomycin-resistant Rev 1 strain from a streptomycin-dependent population selected from a virulent field strain of Brucella melitensis. The Rev 1 strain has been used successfully as a vaccine for the control of brucellosis in sheep and goat populations in many countries (Elberg and Meyer, 1958; Report, 1986). This vaccine has not been used in China, however, where reliance has been placed on the attenuated $B$. suis strain 2 vaccine (Xie Xin, 1986). The latter has been used successfully as an orally administered vaccine to control ovine and caprine brucellosis over large areas of Northern China. However, the $B$. suis strain 2 retains a low degree of residual virulence when injected parenterally and is not recommended for use in pregnant animals (Xie Xin, 1986). For this reason attempts were made to select a completely attenuated but immunogenic variant of this strain through the agency of a mutagen, diethyl sulphate (DES).

Received 3 Oct. 1988; accepted 21 March 1989

\section{Materials and methods}

\section{Brucella strains}

B. suis strain 2 was as described by Xie Xin (1986); it was maintained in the lyophilised condition until required. Cultures were propagated on Nutrient Agar incubated aerobically at $37^{\circ} \mathrm{C}$ for $2-3$ days. B. suis strain 1330 was the virulent biovar 1 reference strain. $B$. melitensis Rev 1 was originally obtained from Professor S. S. Elberg, University of Berkeley, CA, USA. B. melitensis strain 28 , a virulent field strain, was from the Institute culture collection.

\section{Selection of mutants}

Diethyl sulphate (DES) was obtained from the Institute of General Microbiology, Chinese Academy of Science, Beijing, China. A freshly grown suspension of $B$. suis strain 2 was prepared in nutrient broth to give a concentration of about $10^{7}$ cells $/ \mathrm{ml}$. These were added to equal volumes of DES diluted in nutrient broth to give final concentrations between $3 \%$ and $20 \% \mathrm{v} / \mathrm{v}$ and the mixtures were incubated at $37^{\circ} \mathrm{C}$ for $1 \mathrm{~h}$. Samples were then plated on to nutrient agar and incubated at $37^{\circ} \mathrm{C}$ for 3-5 days. Exposure to DES killed most of the organisms but colonies produced by the survivors were picked off and assessed for their cultural properties. Those that were obviously dissociated to non-smooth or grossly aberrant forms were discarded. Colonies with properties typical of smooth $B$. suis biovar 1 were propagated and assessed for virulence.

\section{Assessment of virulence}

The growth obtained from each selected mutant was suspended in sterile saline and adjusted against the 
Chinese national reference standard for opacity to a concentration corresponding to $4 \times 10^{8} \mathrm{cells} / \mathrm{ml}$ of which about $67 \%$ were viable. Doses of $4 \times 10^{8}$ cells were then injected intraperitoneally into groups of four locally bred Swiss mice. Deaths were recorded over the succeeding 7 days. The parent $B$. suis strain 2 was used as a control for residual virulence which was expressed as the LD50 calculated by the method of Reed and Muench (1938). Strains of low virulence according to the mouse test were also tested in guinea-pigs and pregnant sheep. The guinea-pigs were given a subcutaneous injection of $c .10^{9}$ viable organisms and at necropsy, 4 weeks later, the presence of abscesses at the injection site, splenic enlargement and the concentration of Brucella organisms in the spleen tissue were determined.

Virulence for pregnant ewes was determined by subcutaneous injection of $5 \times 10^{9}$ viable organisms at about mid-gestation. Any animals aborting and all those proceeding to term were examined for the presence of brucellae in the placenta and vaginal discharges.

\section{Determination of stability}

To check for stability of virulence, mutants were subjected to serial passage on nutrient agar and then reexamined by the in-vivo test. Those which proved to be stable under these conditions in both in vitro properties and LD50 for mice were subjected to further passage through guinea-pigs and swine. Guinea-pigs were given subcutaneous injections of $1 \times 10^{9}$ viable organisms and the LD50 for mice was determined on selected colonies recovered from the spleen tissue 30 days later. Nonpregnant pigs were given subcutaneous injections of $2 \times$ $10^{10}$ viable organisms and the LD50 for mice was determined on cultures recovered from lymph nodes 30 days later. Non-pregnant ewes were given subcutaneous injections of $4 \times 10^{10}$ viable organisms and mouse LD50 values were determined on isolates obtained from the lymph nodes and spleen tissue 30 days later.

\section{Assessment of protective immunity}

Groups of guinea-pigs were immunised by the subcutaneous route with standard doses of $2 \times 10^{8}$ cells of the mutant strains and the parent vaccine strain. After an interval of 30 days they were challenged by subcutaneous injection of 50 viable organisms of the virulent $B$. melitensis strain 28 . After 30 days the animals were killed and samples of blood, bone marrow, kidney, liver, lung, lymph nodes, spleen, testis and ovary were cultured. The protection index was estimated as the number of animals that gave positive cultures for $B$. melitensis divided by the total number. Ewes were vaccinated by the subcutaneous route with doses of $(2 \cdot 5-5) \times 10^{9}$ viable organisms or by the oral route with doses of $0.5,5$ or 10 , $\times 10^{9}$, viable organisms and challenged $90-150$ days later with $(1-1 \cdot 5) \times 10^{9}$ viable organisms of $B$. melitensis strain 28 given orally. Protection was assessed by determining the proportion of animals undergoing culturally positive abortion and by the proportion found culturally positive at post-mortem examination.

The durability of protective immunity was evaluated by vaccinating $6-7$ month-old lambs by the subcutaneous route with doses of $5 \times 10^{9}$ organisms. The animals were examined for serological evidence of brucellosis 3 months later. At 1-year intervals at the beginning of the mating season, the groups were challenged by the oral administration of doses of $1.5 \times 10^{9}$ organisms of $B$. melitensis strain 28 . The proportion of animals proceeding to normal full term lambing and the proportion aborting as a result of brucellosis were then determined. The total proportion of infected animals was assessed by cultural examination of tissues collected at necropsy 30 days after challenge.

\section{Field evaluation of vaccine}

A field trial of $B$. suis strain 105 was performed in an area in which $B$. melitensis infection was known to be prevalent. Of the total sheep population of approximately 5000 animals, half was vaccinated by subcutaneous injection of $5 \times 10^{8}$ viable organisms of $B$. suis strain 105 , irrespective of age or pregnancy status. All aborted fetuses were cultured for Brucella and random samples of serum were collected from the lamb population each year. Sera were examined by the serum agglutination and complement fixation-tests with standard antigen according to recommended procedures (Alton et al., 1975).

\section{Results}

\section{Selection of mutants}

At high concentrations DES produced complete killing of the $B$. suis strain 2 inoculum but at concentrations of $12.5 \%$ or less, a significant number of organisms survived. This increased from $0.6 \%$ of the inoculum of about $10^{8}$ organisms at a concentration of DES $12.5 \% \mathrm{v} / \mathrm{v}$, to $16.7 \%$ of the inoculum at DES $6.25 \% \mathrm{v} / \mathrm{v}$. Most of the colonies produced by the survivors were of the unstable or dissociated type. However, from 234 colonies of smooth type, 67 mutants were obtained and of these, two, designated strains 71 and 201 , were identified as of reduced virulence by the screening test in mice. Strain 71 was re-exposed to DES $10 \% \mathrm{v} / \mathrm{v}$, and from 260 colonies, 67 mutants were identified of which four proved to be stable and of reduced virulence. From these, mutant strain 105 was selected for further examination.

\section{Virulence of mutant and reference strains}

Comparison of the virulence of mutant strains 105 and 201 with that of the parent $B$. suis strain 2 , the virulent $B$. suis biovar 1 reference strain 1330 and the vaccine strains $B$. abortus strain 19 and $B$. 
melitensis Rev 1, showed that both mutants were of considerably reduced virulence. In terms of the mouse LD50 and pathogenicity for guinea-pigs strain 105 was of lower virulence than any of the other strains examined except for $B$. melitensis $\mathrm{Rev}$ 1 (table I).

In pregnant ewes, strain 105 showed evidence of further reduced virulence. Whereas the parent $B$. suis strain 2 inoculated subcutaneously in doses of $5 \times 10^{9}$ viable organisms produced abortion with positive cultures in 7 of 14 animals, strain 105 , under the same conditions, failed to produce abortion in any of 50 ewes and the organisms could not be recovered at lambing. In comparison, $B$. melitensis $\operatorname{Rev} 1$, when injected subcutaneously in doses of $1.5 \times 10^{9}$ viable organisms, produced abortion in 13 of 14 pregnant ewes. Unlike the parent strain which produced appreciable postvaccination reactions in 6 of 10 ewes inoculated, marked by temperature rises of $1-1 \cdot 5^{\circ} \mathrm{C}$, loss of appetite and inability to follow the moving flock, strain 105 did not produce any evidence of reaction in 14 animals closely studied. Strain 105 did not produce persistent serological titres after parenteral injection (table II). When examined over a period of 11 months, all sheep vaccinated with strain 105 became negative in the complement fixation test within 6 months and none had significant agglutinin titres by the eleventh month.

\section{Stability of mutant strains}

The stability of the mutant strains was confirmed by retention of their in-vitro and in-vivo properties following serial passage through culture media and through various species of animals. Little fluctuation in virulence was seen following passage of strains 105 and 201 on nutrient agar until the fortieth passage, when strain 105 showed a further reduction in virulence for mice and guinea-pigs and strain 201 gave indications of increased virulence (table III).

After five passages through guinea-pigs and three passages through ewes, strain 105 showed a trend towards a reduction in virulence for mice whereas strain 201 showed a trend towards increased virulence. After five passages through non-pregnant swine, strain 105 showed a tendency towards

Table I. Virulence of mutants and reference strains in mice and guinea-pigs

\begin{tabular}{|c|c|c|c|c|c|}
\hline \multirow[b]{3}{*}{ Strains } & \multirow{3}{*}{$\begin{array}{c}\text { Mouse } \\
\text { LD50 } \\
\left(\times 10^{8}\right)\end{array}$} & \multicolumn{4}{|c|}{ Guinea-pigs } \\
\hline & & \multicolumn{2}{|c|}{ subcutaneous abscess } & \multirow[b]{2}{*}{$\begin{array}{l}\text { spleen wt/ } \\
\text { body weight }\end{array}$} & \multirow{2}{*}{$\begin{array}{c}\text { spleen coun } \\
\text { (number of } \\
\text { brucella } \\
\text { cells } / g \text { ) }\end{array}$} \\
\hline & & $\begin{array}{l}\text { number } \\
\text { positive }\end{array}$ & $\begin{array}{c}\text { number } \\
\text { tested }\end{array}$ & & \\
\hline B. suis mutant 105 & $166 \cdot 0$ & 1 & 10 & $0 \cdot 13$ & $4.0 \times 10^{3}$ \\
\hline B. suis mutant 201 & $97 \cdot 0$ & 0 & 10 & 0.21 & $1.5 \times 10^{4}$ \\
\hline B. suis strain 2 & $29 \cdot 7$ & 6 & 10 & $0 \cdot 21$ & $2.0 \times 10^{4}$ \\
\hline B. abortus 19 & 118.9 & 2 & 4 & $0 \cdot 19$ & $8.9 \times 10^{4}$ \\
\hline B. suis 1330 & $3 \cdot 8$ & 8 & 8 & 0.42 & $5 \cdot 17 \times 10^{6}$ \\
\hline B. melitensis $\operatorname{Rev} 1$ & $268 \cdot 0$ & 0 & 4 & $0 \cdot 16$ & $2 \cdot 0 \times 10^{3}$ \\
\hline
\end{tabular}

Table II. Serological response of sheep to subcutaneous injection of B. suis strain 105

\begin{tabular}{|c|c|c|c|c|c|c|c|c|c|c|c|c|c|}
\hline \multirow{2}{*}{$\begin{array}{l}\text { Time } \\
\text { (months) }\end{array}$} & \multirow{2}{*}{$\begin{array}{l}\text { Number of } \\
\text { animals } \\
\text { inoculated }\end{array}$} & \multicolumn{7}{|c|}{$\begin{array}{l}\text { Serum agglutination test; number of sera with } \\
\text { titre }\end{array}$} & \multicolumn{5}{|c|}{$\begin{array}{l}\text { Complement fixation test; number } \\
\text { of sera with titre }\end{array}$} \\
\hline & & 25 & 50 & 100 & 200 & 400 & 800 & 1600 & 5 & 10 & 20 & 40 & 80 \\
\hline 1 & 159 & 0 & 21 & 30 & 65 & 38 & 5 & 0 & 8 & 84 & 59 & 8 & 0 \\
\hline 3 & 144 & 8 & 29 & 68 & 32 & 7 & 0 & 0 & 73 & 54 & 6 & 0 & 0 \\
\hline 6 & 120 & 41 & 56 & 9 & 0 & 0 & 0 & 0 & 0 & 0 & 0 & 0 & 0 \\
\hline 9 & 121 & 29 & 38 & 9 & 0 & 0 & 0 & 0 & 0 & 0 & 0 & 0 & 0 \\
\hline 11 & 105 & 1 & 1 & 0 & 0 & 0 & 0 & 0 & 0 & 0 & 0 & 0 & 0 \\
\hline
\end{tabular}


Table III. The stability of the virulence of $B$. suis mutants and parent strain after serial passage through culture media and animals

\begin{tabular}{|c|c|c|c|c|c|c|c|c|c|}
\hline \multirow{3}{*}{$\begin{array}{c}\text { Brucella } \\
\text { strain }\end{array}$} & \multicolumn{9}{|c|}{ LD50 in mice $\left(\times 10^{8}\right)$ after passages $(n)$ in } \\
\hline & \multicolumn{3}{|c|}{ culture media } & \multicolumn{3}{|c|}{ guinea-pigs } & \multicolumn{3}{|c|}{ ewes } \\
\hline & 0 & 5 & 40 & 0 & 3 & 5 & 1 & 2 & 3 \\
\hline mutant 105 & $166 \cdot 6$ & $197 \cdot 0$ & $270 \cdot 0$ & $101 \cdot 3$ & $105 \cdot 3$ & $133 \cdot 0$ & $127 \cdot 0$ & $194 \cdot 0$ & $155 \cdot 8$ \\
\hline mutant 201 & $97 \cdot 0$ & $90 \cdot 8$ & $71 \cdot 3$ & $164 \cdot 9$ & $86 \cdot 7$ & $90 \cdot 8$ & $130 \cdot 0$ & $90 \cdot 0$ & $75 \cdot 6$ \\
\hline B. suis 2 & $29 \cdot 7$ & $28 \cdot 2$ & $28 \cdot 3$ & $25 \cdot 2$ & $20 \cdot 0$ & $28 \cdot 2$ & & ND & \\
\hline
\end{tabular}

$\mathrm{ND}=$ not done

Table IV. Stability of mutants in virulence after serial passages through swine

\begin{tabular}{|c|c|c|c|c|c|}
\hline \multirow[b]{3}{*}{$\begin{array}{l}\text { Brucella } \\
\text { strain }\end{array}$} & \multirow[b]{3}{*}{$\begin{array}{l}\text { Number of } \\
\text { passages }\end{array}$} & \multicolumn{3}{|c|}{ Virulence for guinea-pigs } & \multirow{3}{*}{$\begin{array}{l}\text { Virulence fo } \\
\text { mice; } \text { LD50 } \\
\left(\times 10^{8} \text { cells }\right)\end{array}$} \\
\hline & & \multicolumn{2}{|c|}{ Local abscess } & \multirow[b]{2}{*}{$\begin{array}{c}\text { spleen, } \\
\text { Brucella } \text { cells/g }\end{array}$} & \\
\hline & & $\begin{array}{l}\text { number } \\
\text { positive }\end{array}$ & $\begin{array}{l}\text { number } \\
\text { tested }\end{array}$ & & \\
\hline mutant 201 & $\begin{array}{l}1 \\
2 \\
3 \\
4 \\
5\end{array}$ & $\begin{array}{l}2 \\
0 \\
0 \\
0 \\
0\end{array}$ & $\begin{array}{l}5 \\
5 \\
5 \\
5 \\
5\end{array}$ & $\begin{array}{c}4.85 \times 10^{3} \\
2.05 \times 10^{4} \\
3.43 \times 10^{4} \\
3.06 \times 10^{4} \\
0\end{array}$ & $\begin{array}{l}154 \cdot 2 \\
178 \cdot 2 \\
160 \cdot 4 \\
140 \cdot 0 \\
170 \cdot 0\end{array}$ \\
\hline mutant 105 & $\begin{array}{l}1 \\
2 \\
3 \\
4 \\
5\end{array}$ & $\begin{array}{l}0 \\
0 \\
0 \\
0 \\
2\end{array}$ & $\begin{array}{l}5 \\
5 \\
5 \\
5 \\
5\end{array}$ & $\begin{array}{c}3.71 \times 10^{4} \\
7.93 \times 10^{3} \\
2.74 \times 10^{4} \\
6.3 \times 10^{3} \\
0\end{array}$ & $\begin{array}{l}240 \cdot 0 \\
240 \cdot 0 \\
240 \cdot 0 \\
150 \cdot 0 \\
173 \cdot 1\end{array}$ \\
\hline B. suis 2 & 0 & 5 & 5 & 0 & $30 \cdot 0$ \\
\hline
\end{tabular}

slightly increased virulence for mice whereas no consistent trend was discernible for strain 201. For both strains however, the LD50 remained very much greater than that of the parent strain (table IV).

\section{Stimulation of protective immunity}

The protective efficacy of $B$. suis strain 105 against infection by virulent $B$. melitensis in guineapigs was comparable with that of the parent strain and considerably better than that of strain 201 (table V). In sheep, both strains 105 and 201 gave a level of protection similar to that of $B$. melitensis Rev 1 when administered by the sub-cutaneous route. Strain 105 was much more effective than $B$. melitensis Rev 1 when given by the oral route (table VI).

The immunity was maintained at a high level for at least 3 years although a slight decline in protective efficacy was apparent by the end of the third year. Assessment at this stage was complicated by the development of appreciable natural immunity in the control group, presumably as a result of exposure to sub-clinical infection (table VII). Under field conditions, $B$. suis strain 105 behaved as an effective vaccine. In the trial area, in the first year after vaccination, only two $B$. melitensis isolates were recovered from aborted fetuses and there were no isolates in the subsequent 3 years. A survey of random samples of lamb sera showed that $21.6 \%$ $(\mathrm{n}=134)$ were positive in the complement fixation 
Table V. Protection of guinea-pigs vaccinated with $B$ suis strain 2 and mutant strains 105 and 201 against challenge with $B$. melitensis strain 28

\begin{tabular}{lc|ccc}
\hline & & \multicolumn{3}{|c}{ Protective efficacy } \\
\cline { 3 - 5 } $\begin{array}{c}\text { Vaccine } \\
\text { strain }\end{array}$ & $\begin{array}{c}\text { Number of } \\
\text { days before } \\
\text { challenge }\end{array}$ & $\begin{array}{c}\text { Number } \\
\text { tested }\end{array}$ & $\begin{array}{c}\text { Number } \\
\text { infected }\end{array}$ & $\begin{array}{c}\text { Percentage } \\
\text { protection }\end{array}$ \\
\hline B. suis 2 & 75 & 10 & 1 & 90 \\
mutant 105 & 30 & 26 & 5 & $80 \cdot 7$ \\
mutant 201 & 75 & 10 & 2 & $80 \cdot 0$ \\
& 30 & 10 & 6 & $40 \cdot 0$ \\
none & 75 & 10 & 6 & 40.0 \\
& NA & 10 & 10 & 0 \\
\hline
\end{tabular}

$\mathrm{NA}=$ not applicable. or serum agglutination test in the first year, falling to $1.79 \%(n=167)$ in the second year with no positive samples in the third year.

\section{Discussion}

The main aim of this study was to select a stable mutant of $B$. suis strain 2 which met the required standards of safety for the parenteral route of immunisation while retaining the full protective efficacy of the parent strain. The latter is widely used for oral immunisation of sheep and goats in China but is prohibited for parenteral injection because of the risk of producing abortion if pregnant animals are inadvertently inoculated, an often unavoidable occurrence under field conditions.

Table VI. Effect of vaccine strains on resistance of sheep to oral challenge with $B$. melitensis strain 28

\begin{tabular}{|c|c|c|c|c|c|c|c|}
\hline \multirow[b]{2}{*}{$\begin{array}{l}\text { Vaccine } \\
\text { strain }\end{array}$} & \multirow[b]{2}{*}{ Route } & \multirow[b]{2}{*}{$\begin{array}{c}\text { Vaccine dose } \\
\times 10^{9}\end{array}$} & \multirow[b]{2}{*}{$\begin{array}{l}\text { Days of } \\
\text { challenge }\end{array}$} & \multirow[b]{2}{*}{$\begin{array}{l}\text { Challenge } \\
\text { dose } \times 10^{9}\end{array}$} & \multicolumn{3}{|c|}{ Protective efficacy } \\
\hline & & & & & $\begin{array}{c}\text { number of } \\
\text { ewes }\end{array}$ & $\begin{array}{c}\text { number of } \\
\text { abortions/ } \\
\text { number } \\
\text { infected }\end{array}$ & $\begin{array}{l}\text { Percent } \\
\text { protected }\end{array}$ \\
\hline \multirow{5}{*}{$\begin{array}{l}\text { B. suis } \\
\text { strain } 2 \\
\text { mutant } 105\end{array}$} & s.c. & $1 \cdot 2$ & 120 & $1 \cdot 0$ & 14 & $3 / 3$ & $78 \cdot 6$ \\
\hline & oral & $25 \cdot 0$ & 120 & $1 \cdot 0$ & 14 & $4 / 5$ & $64 \cdot 3$ \\
\hline & s.c. & 5 & 150 & 1 & 15 & $1 / 2$ & $86 \cdot 4$ \\
\hline & oral & 10 & 150 & $1 \cdot 5$ & 21 & $3 / 5$ & 76 \\
\hline & s.c. & 0.5 & 120 & 1 & 15 & $2 / 3$ & 80 \\
\hline mutant 201 & s.c. & 5 & 150 & 1 & 14 & $2 / 4$ & $78 \cdot 6$ \\
\hline B. melitensis & s.c. & $1 \cdot 5$ & 90 & $1 \cdot 5$ & 5 & $1 / 1$ & 80 \\
\hline Rev 1 & oral & $1 \cdot 5$ & 90 & $1 \cdot 5$ & 5 & $3 / 3$ & 40 \\
\hline None & N.A. & N.A. & N.A. & $1 \cdot 5$ & 12 & $10 / 12$ & 0 \\
\hline
\end{tabular}

N.A. $=$ not applicable $;$ s.c. $=$ subcutaneous.

Table VII. Duration of protection against oral challenge with $B$. melitensis strain 28 in ewes vaccinated as lambs with $B$. suis strain 105

\begin{tabular}{|c|c|c|c|c|c|c|}
\hline $\begin{array}{c}\text { Year of } \\
\text { challenge }\end{array}$ & $\begin{array}{l}\text { Vaccination } \\
\text { status }\end{array}$ & $\begin{array}{c}\text { Total number } \\
\text { of ewes }\end{array}$ & $\begin{array}{c}\text { Total number } \\
\text { of infected } \\
\text { ewes }\end{array}$ & $\begin{array}{l}\text { Total number } \\
\text { of aborted ewes }\end{array}$ & $\begin{array}{c}\text { Total number } \\
\text { of normal } \\
\text { births }\end{array}$ & $\begin{array}{l}\text { Percentage } \\
\text { protection }\end{array}$ \\
\hline 1st year & $\begin{array}{l}\text { vaccinated } \\
\text { unvaccinated }\end{array}$ & $\begin{array}{l}15 \\
15\end{array}$ & $\begin{array}{r}2 \\
15\end{array}$ & $\begin{array}{r}2 \\
13\end{array}$ & $\begin{array}{r}13 \\
2\end{array}$ & $\begin{array}{r}86 \cdot 7 \\
0 \cdot 0\end{array}$ \\
\hline 2nd year & $\begin{array}{l}\text { vaccinated } \\
\text { unvaccinated }\end{array}$ & $\begin{array}{l}15 \\
15\end{array}$ & $\begin{array}{r}2 \\
14\end{array}$ & $\begin{array}{r}2 \\
11\end{array}$ & $\begin{array}{r}13 \\
3\end{array}$ & $\begin{array}{c}86.7 \\
6 \cdot 6^{*}\end{array}$ \\
\hline 3 rd year & $\begin{array}{l}\text { vaccinated } \\
\text { unvaccinated }\end{array}$ & $\begin{array}{l}13 \\
13\end{array}$ & $\begin{array}{r}3 \\
11\end{array}$ & $\begin{array}{l}2 \\
6\end{array}$ & $\begin{array}{r}12 \\
5\end{array}$ & $\begin{array}{l}72 \cdot 7 \\
15 \cdot 3^{*}\end{array}$ \\
\hline
\end{tabular}

\footnotetext{
* Immunity acquired by exposure to natural infection.
} 
The mutagen DES was effective in producing a mutant of suitable properties by the two stage process described. In practice, only a very small proportion of the organisms surviving the mutagen treatment were sufficiently stable and of adequately reduced virulence to be candidate vaccines. Nevertheless, the screening process used, that of determining the mouse LD50, was effective in identifying suitably attenuated strains and the stability and immunogenicity of the most effective of these was confirmed by inoculation of guinea-pigs and pregnant ewes. The protective efficacy of this strain when used as a vaccine under field conditions was confirmed by the results of the field trial. The reduction in the infection rate from $21.6 \%$ of sero-

\section{REFERENCES}

Alton G G, Jones L M, Pietz D E 1975 Laboratory techniques in brucellosis, 2nd edn. World Health Organization Monograph series No. 55 .

Auerbach C 1967 The chemical production of mutations. The effect of chemical mutagens on cells and their genetic material is discussed. Science 158: 114-117.

Elberg S S, Faunce K 1957 Immunization against Brucella infection IV. Immunity conferred on goats by a non dependent mutant from a streptomycin-dependent mutant strain of Brucella melitensis. Journal of Bacteriology 73: 211 217.

Elberg S S, Meyer K F 1958 Caprine immunization against brucellosis. A summary of experiments on the isolation, positive animals in the first year to $0 \%$ in the third year provides strong circumstantial evidence of the efficacy of this strain.

The nature of the genetic change responsible for the attenuation produced as a result of DES treatment is not clear. DES is an alkylating agent and produces cross-linking of DNA polynucleotide strands at multiple points. In most instances the effect of this will be lethal to the organism. However, by careful selection of survivors it is possible to obtain stable mutants of the required properties. Molecular studies of the DNA of strain 105, its parent strain and fully virulent field strains of $B$. suis biovar 1 could provide an insight into the genetic basis of the virulence of Brucella.

properties and behaviour of a vaccine strain. Bulletin of the World Health Organization 19: 711-724.

Pelecanos M, Anderson T 1964 The mutagenic activity of diethyl sulfate in Drosophila melanogaster 1. The dose-mutagenic response to larval and adult feeding. Mutation Research 1 : 173-178.

Reed L J, Muench H 1938 A simple method of estimating fifty per cent endpoints. American Journal of Hygiene 27: 493497.

Report 1986 Joint FAO/WHO Expert Committee on Brucellosis, Sixth Report. World Health Organization Technical Report Series No. 740.

Xie Xin 1986 Orally administrable brucellosis vaccine: Brucella suis strain 2 vaccine. Vaccine 4: 212-216. 